NASA Contractor Report 189207

AIAA-92-3069

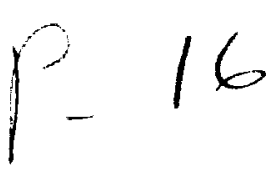

\title{
A Comparison of the Calculated and Experimental Off-Design Performance of a Radial Flow Turbine
}

\section{Lizet Tirres}

Sverdrup Technology, Inc.

Lewis Research Center Group

Brook Park, Ohio

July 1991

Prepared for

Lewis Research Center

Under Contracts NAS3-25266

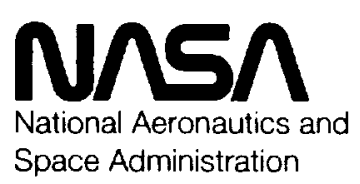

$$
\begin{aligned}
& \text { (NASA-CR-189207) A COMPARISUN OF THE } \\
& \text { CALCULATED ANO EXPERIMENTAL LFF-DESIGN } \\
& \text { N92-29402 } \\
& \text { PERFORMANCE OF A RADIAL FLOW TURBINE Final } \\
& \text { Roport (Sverdrup Technology) } 16 \mathrm{p}
\end{aligned}
$$




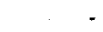




\title{
A Comparison of the Calculated and Experimental Off-Design Performance of a Radial Flow Turbine
}

\author{
Lizet Tirres \\ Sverdrup Technology, Inc. \\ Brookpark, OH 44142
}

\begin{abstract}
$\underline{\text { Abstract }}$
Off-design aerodynamic performance of the solid version of a cooled radial inflow turbine is analyzed. Rotor surface static pressure data and other performance parameters were obtained experimentally. Overall stage performance and turbine blade surface static to inlet total pressure ratios were calculated by using a quasi-three-dimensional inviscid code. The off-design prediction capability of this code for radial inflow turbines shows accurate static pressure prediction. Solutions show a difference of 3 to 5 points between the experimentally obtained efficiencies and the calculated values.
\end{abstract}

\section{Introduction}

The radial turbine offers advantages over the axial turbine because of its high stage work and its ability to perform at a higher efficiency at low equivalent flow. A coolant scheme enhances the radial turbine's advantages and potential uses. A cooled radial turbine allows operation at a higher inlet temperature. With the ability to operate in a higher temperature regime, the radial turbine can be used as a primary power source, particularly in small turbine engines.

NASA's cooled radial turbine research program includes one of many efforts at improving small engine performance by employing the advantages already mentioned. NASA and the Army have sponsored several

This paper is declared work of the U.S. Government and is not subject to copyright protection in the United States. programs involving fabrication techniques for the manufacture of cooled radial turbines. Reference 1 describes the fabrication and testing of a radial turbine stage with air cooled nozzle and rotor sections. Reference 2 presents the results of an aerodynamic test using a cooled rotor made by bonding a cast MAR-M247 air-cooled shell to a p101 powder metal hub. An attempt at fabricating and evaluating a cooled radial turbine that features directionally solidified (DS) MAR-M247 laminated blades is summarized in reference 3. Reference 4 discusses a split blade fabrication method for a cooled radial turbine. These fabrication techniques address the difficulties associated with the manufacture of a cooled radial turbine.

NASA's most recent effort involves a NASA/Allison design of a metallic air-cooled radial turbine. In reference 5 , Snyder and Roelke describe this design that includes rotor cooling requirements and accounts for rotor fabrication constraints. Allison fabricated solid and hollow (cooled) scaled models of this rotor. The rotors have identical external geometries. Test plans for these two rotors include an overall stage aerodynamic evaluation and analysis of the stage including blade surface measurements from the rotating rotor. Reference 6 discusses the initial design condition analysis. This report describes the initial off-design aerodynamic performance testing using the solid version of this NASA/Allison rotor. It compares the resulting experimental data with the solutions 
that were obtained by using MTSB, a quasi-three dimensional inviscid flow solver. This flow solver is coupled with boundary layer analysis (MERIDL/TSONIC/BLAYER).

\section{Stage Description}

The rotor was scaled up by a factor of 1.8 for ease in instrumentation and was cast from MAR-M247, a high-temperature alloy. Physical characteristics of the stage include a stator with 15 vanes having a chord length of 5 inches. The vanes turn the flow approximately 73 degrees. As seen in figure 1 , the rotor has 13 blades with a circular leading edge and a scalloped backface. The inlet tip diameter is 14.4 inches and the exit shroud diameter is 9.39 inches. Table 1 compares the engine-sized design value with those for the test rotor. Test conditions were chosen to match engine design Reynolds number and Mach number. With a test design speed of nearly $20,000 \mathrm{rpm}$, the scaled test rotor ran at conditions between 80 and 120 percent of that speed. It operated in a stage pressure ratio range $\left(\mathrm{P}_{0}^{\prime} / \mathrm{P}_{4}^{\prime}\right)$ between 2.0 and 5.5 with design at 4.0. Blade surface pressure measurements were obtained at 80,90 , and 100 percent design speed at pressure ratios $3.5,4$, and 4.5 .

\section{Apparatus, Instrumentation, and Procedure}

Nowlin and Verhoff describe the test equipment and facility capabilities of NASA Lewis' Small Engine Components Test Facility (SECTF) in reference 7 . Figure 2 shows a schematic of the SECTF with the test turbine located in the annular plenum. The natural gas combustor allows for testing at a wide range of temperatures $(<800 \mathrm{~F})$ and the eddy-current dynamometer absorbs power and controls the speed up to $60,000 \mathrm{rpm}$. Other facility components include: a chilled air system, an in-line torquemeter, and a speed reduction gearbox.

Figure 3 shows a cross section of the turbine test package. Flow field instrumentation displays and records Several parameters at six locations along the flow path, from station zero at the inlet to station four which is located downstream of the rotor exit.

The turbine test package includes six probes that record tip clearances during the test runs. Three tip clearance probes measure axial shroud clearances at the inducer at evenly distributed circumferential locations. Similarly, 3 probes monitor radial tip clearance at the exit of the rotor. During testing, the probes recorded average tip clearances of 34 mils at the inlet and 16.5 mils at the exit. The stationary backface clearance measured 58 mils before and after the test runs.

A venturi flow meter upstream of the inlet plenum measured the air flow. The total mass flow included air and fuel mass flows. The normalized total pressure, $\delta$, the square root of the normalized total temperature, $\theta \mathrm{cr}$, and a corrected ratio of specific heats, $\varepsilon$, allowed the calculation of equivalent conditions. Multiplying the total mass flow by the equivalent parameters determined the equivalent mass flow,

$$
m_{e q}=\frac{m \varepsilon \sqrt{\theta_{c r}}}{\delta}
$$

The equivalent mass flow is presented in terms of pounds per second.

The instrumentation used to determine the overall efficiency included the stationary rakes at stations 0 and 4 . Traversing probes at station 3 measured the exiting flow angles as a function of span in rotor exit surveys. These exit surveys provide the station 4 rake angle 
settings so that the rakes can be aligned with the exiting flow while they remained within the probe incidence limit $\left( \pm 10^{\circ}\right)$. The actual specific work was calculated by two methods. The first method, based on temperature, used the total temperatures from the inlet and exit rakes at stations 0 and 4 . The second method used the total turbine torque to decide specific work. Because both methods provided similar values for specific work, the efficiencies in this comparison used the specific work based on temperature. The ideal value of enthalpy change was determined by using the measured total pressures at stations 0 and 4 . The efficiency, $\eta_{\mathrm{T} 4}^{\prime}$, presented in this paper is the observed change in enthalpy, $\Delta \mathrm{h}_{\mathrm{T} 4}^{\prime}$, divided by the ideal change,

$$
\eta_{T 4}^{\prime}=\frac{\Delta h_{T 4}^{\prime}}{\Delta h_{\text {ideal }}^{\prime}} \text {. }
$$

A series of pressure taps, between stations 1 and 2, measured static pressure on both endwalls and on the stator surface. A profile of the stator vane shows the location of the static pressure taps on the vane surface in figure 4. Fourteen static taps circumscribed the meridional streamline of one stator vane with two additional taps at the leading edge, one near the hub and one near the tip. The throat region contained two additional taps similarly situated. The stator comparison values consisted of the ratios of the static pressure measurement, Ps, to the total inlet pressure, $\mathrm{P} 0$ ', obtained from the rakes at station 0.

Figure 5 shows the location of the 36 pressure taps on the rotor. These taps measured static pressures on the rotating rotor. Fourteen taps on the 20 percent streamline measured static pressures on both the pressure and suction sides of the rotor. Similarly, 14 taps on the 70 percent streamline measured static pressures on both pressure and suction sides of the blade. Eight additional taps measured hub static pressures.

A Rotating Data Package (RDP) recorded the 36 surface static pressures during testing. Reference 8 describes the modification of a standard Scanivalve system. The RDP used a series resistor network connected to unused thermocouple leads. Each time the RDP stepped to a new port, the number of series resistors in the circuit increased. The output terminals of the RDP measured the voltage across the resistor. Each port location having a specific expected voltage output could then be identified. The correction due to the centrifugal pumping head relates the measured rotating pressures to the axis of rotation. Reference 9 discusses the pressure correction employed in this experiment. A differential equation that contains radius, temperature, and speed terms is solved and is used to calculate the ratio of pressures between the measurement radius and the transducer location (the centerline). The solution assumes a constant temperature in the pressure tube. The pressure correction is

$$
P_{R i, c o r r}=P_{R i} e^{\left[\frac{\mathrm{cn}^{2}\left(r_{i}^{2}-r_{09}^{2}\right)}{2 R T_{g c}}\right]}
$$

Where:

$\mathrm{P}_{\mathrm{Ri}}=$ measured static pressure at port $\mathrm{i}$, psi

$r_{i}=$ radial distance of port $i$ to the shaft centerline, $\mathrm{ft}$

$r_{0}=$ radial location of the transducer, $\mathrm{ft}$

$\mathrm{R}=$ gas constant, $\mathrm{ft}-\mathrm{lbf} / \mathrm{lbm}-\mathrm{R}$

$T=$ averaged inlet and exit total

temperature, $\mathrm{R}$

$\mathrm{g}_{\mathrm{c}}=$ conversion constant, 32.174

$\mathrm{lbm}-\mathrm{ft} / \mathrm{lbf}-\mathrm{s}^{2}$

$\omega=$ rotational speed, radians $/ \mathrm{sec}$

Because surface temperatures were not measured and tube temperature measurements were impossible for this experiment. The value for temperature in the pressure correction is an average of the total inlet 
temperature obtained from the rakes at station 0 and the total exit temperature obtained from the rakes at station 4 . Described below, the computer code used in this aerodynamic comparison can calculate static temperatures at a specific location along the rotor streamline. MTSB generated static blade temperatures do not significantly change the pressure correction and so the averaged inlet and exit total temperatures provided values for temperature in the pressure correction.

\section{Analytical Method}

The computational method used in this comparison incorporates the coupling of three codes, MERIDL, TSONIC, and BLAYER (MTSB). Boyle, Haas, and Katsanis describe their modification of MERIDL and TSONIC, in reference 10 . In reference 11 , Simonyi and Boyle describe additional loss modifications specifically associated with the radial turbine. MTSB allows for prediction of overall losses as part of the aerodynamic analysis. It is a robust code that can predict axial turbine performance accurately. However, 5 and 11 show that MTSB requires additional modifications to improve the accuracy of the radial inflow turbine case solutions.

MTSB iteratively obtains flow field solutions on hub-to-shroud (mid-channel) and blade-to-blade surfaces until pressure and suction surface trailing-edge velocities are equal. It includes an initially assumed pressure drop associated with clearance, frictional, incidence, profile, and secondary flow losses. Using the resulting quasi-3D streamline solutions as input, BLAYER calculates the boundary layer growth along suction, pressure and endwall surfaces. The boundary layer results provide profile losses and, together with correlations, the secondary losses. MTSB includes clearance, incidence, and disk windage models to obtain overall efficiency. If the initially assumed loss does not equal the calculated loss, the quasi-3D flow solution is recalculated until the two are consistent. Using experimental conditions as input, MTSB generated solutions for off-design speed conditions of 80 and 90 percent and pressure ratios of 3.5, 4.5 and 5.5.

\section{Comparison and Discussion of Results}

The results of 4 test cases were compared in terms of stage efficiency, and surface pressure. Two additional cases were used to complete the stage efficiency comparison. The conditions of case 1 are 80 percent design speed and a stage pressure ratio of 3.5. Conditions for case 2 are 80 percent design speed and stage pressure ratio of 4.5 . Cases 3 and 4 are both at 90 percent design speed with the stage pressure ratio conditions of case 3 at 3.5 and case 4 at 4.5 . The stage pressure ratio of cases 5 and 6 was 5.5 with case 5 at 80 percent design speed and case 6 at 90 percent design speed.

Stage Efficiency: Figures 6 and 7 show a comparison of the predicted and measured stage efficiencies at 80 and 90 percent design speed. The two figures illustrate that the MTSB calculations are 3 to 5 points lower than the experimentally derived stage efficiencies. MTSB determines the secondary losses by using correlations. If these correlations are not calibrated, shifting of the stage efficiencies can occur. The MTSB-calculated loss breakdown, figure 8, shows that, for the most part, the clearance losses are the dominant loss in the calculations. The clearance loss accounts for 31 to 35 percent of the total stage loss in test cases 1,2 , and 5 , and 40 to 42 percent in test cases 3,4 , and 6 . Incidence losses account for 13 to 19 percent of the total loss for cases 3 and 4, 22 percent for cases 1 and 6 , and 29 to 33 percent for cases 2 and 5. Another large loss is the profile loss. Fifteen percent of the total overall loss is due to the profile loss in case five. In case 6 , the profile loss is 20 percent of the total loss. Cases 2 and 4 have 
profile loss levels at 24 and 26 percent. Finally, cases 1 and 3 have a profile loss of 29 percent of the total loss.

Again, note that the clearance loss is the largest total loss. Figure 9 shows the loss fraction breakdown, percent of clearance loss, for the 6 cases and compares them with the design condition loss fraction breakdown. The figure shows that levels within the breakdown does not vary. However, in all cases the unusually large backface clearance accounts for more than 76 percent of the total clearance loss.

\section{Stator and Rotor Surface Pressures:} Four experimental test cases with stage pressure ratios of 3.5 and 4.5 at speeds of 80 and 90 percent of design were compared with the calculations. Because this stator is axisymmetric (constant section along the $\mathrm{z}$-axis), only one streamline for each case is shown in figures 10-13. The figures compare the surface static-to-inlet total pressure ratio as a function of relative radius for the stator and surface static-to-inlet total pressure ratio as a function of meridional distance, $M$, at 20 and 70 percent streamline for the rotor. The relative radius is the actual radius, in feet, subtracted from unity and simply orients the vane inlet to the left.

In all four cases, the MTSB stator solution shows a spike that occurs on the suction surface near the throat region. A surface curvature inflection on the stator surface causes some form of the spike to appear at stage pressure ratios as low as 2.0 where the flow is subsonic through the stator, reference 11. Except the size of the spike the MTSB solution is a highly accurate representation of the surface static pressures.

For the rotor, figures 10-13 show good agreement on the pressure side for both streamlines in all four cases. At 80 percent design speed (cases 1 and 2), the boundary layer analysis of the 20 percent streamline shows more loss on the suction side than was measured.

\section{Conclusion}

MTSB provides accurate static pressure predictions for the off-design test cases presented in this report. This comparison illustrates that MTSB can calculate static pressures accurately. As with the design point case the MTSB solution for the non-rotating stator compares well with the experimental data. The difference in magnitude between (the shifting of the measured and calculated stage efficiencies indicate that the distribution level of the losses may need to be reevaluated. Flow leakage not captured by the calculation around the scalloped backface may be a valid explanation for the difference in loss level. The loss models used in MTSB may need recalibration for the radial turbine configuration. The effect of the clearance gap size on efficiency needs to be addressed. If the loss distributions in MTSB can be adjusted, the code will be even more useful in a first-cut analysis than it already is.

\section{References}

1. Calvert, G.S., Beck, S.C., and Okapuu, U., "Design and Experimental Evaluation of a High-Temperature Radial Turbine," USAAMRDL TR-71-20, 1971.

2. Tipton, D.L. and Monson, D.S., "High Temperature Radial Turbine Aero-Test," USAAVRADCOM TR-81-D-19, 1981.

3. Large, G.D., and Meyer, L.J., "Cooled, Variable-Area Radial Turbine Program," NASA CR-165408, 1982.

4. Hammer, A.N., Aigret, G.G., Psichogios, T.P., and Rodgers, C., "Fabrication of 
Cooled Radial Turbine Rotor," NASA CR-179503, 1986.

5. Snyder, P.H., and Roelke, R.J., "The Design of an Air-Cooled Metallic High Temperature Radial Turbine," AIAA Paper No. 88-2872, 1988.

6. Tirres, L., "A Comparison of the Analytical and Experimental Performance of the Solid Version of a Cooled Radial Turbine," NASA CR-187195, 1991.

7. Nowlin, B.C., and Verhoff, V.G., "Small Engine Components Test Facility Turbine Testing Cell," AIAA Paper No. 88-2963, 1988.

8. DiCicco, D., Nowlin, B.C., and Tirres, L., "Description of a Pressure Measurement Technique for Obtaining Surface Static
Pressures of a Radial Turbine," AIAA Paper No. 92-4006, 1992.

9. Chivers, J.W.H., "Blade Pressure Measurements," Rolls-Royce Limited, DCAF 070028, 1982.

10. Boyle, R.J., Haas, J.E., and Katsanis, T., "Comparison Between Measured Turbine Stage Performance and Predicted Performance Using Quasi-3D Flow and Boundary Layer Analysis," NASA TM-83640, AVRADCOM TR-84-C-6, 1984.

11. Simonyi, P.S., and Boyle, R.J., "Comparison of Analysis and Experimental Performance for Three Compact Radial Turbines," AIAA Paper No. 91-2128, 1991. 


\begin{tabular}{|l|c|c|}
\hline & Engine & Test \\
\hline $\mathrm{T}_{0}{ }_{0},{ }^{\circ} \mathrm{R}$ & $2,760.00$ & 859.70 \\
\hline $\mathrm{P}_{0}^{\prime}, \mathrm{psi}$ & 200.00 & 29.80 \\
\hline $\mathrm{m}, \mathrm{lbm} / \mathrm{sec}$ & 4.56 & 4.00 \\
\hline$\Delta \mathbf{h}^{\prime}, \mathrm{Btu} / \mathrm{lbm}$ & 186.85 & 59.61 \\
\hline $\mathrm{N}, \mathrm{rpm}$ & $61,900.00$ & $19,475.34$ \\
\hline $\mathrm{P}_{0}{ }_{0} / \mathrm{P}^{\prime}$ & 3.66 & 4.05 \\
\hline$\eta^{\prime}$, uncooled & 0.87 & 0.87 \\
\hline $\mathrm{Re}$ & $381,622.00$ & $381,622.00$ \\
\hline Power, hp & $1,205.00$ & 337.21 \\
\hline Diameter, inches & 8.02 & 14.40 \\
\hline
\end{tabular}

Table 1. Engine and test design conditions.

\author{
ORIGINAI. PAGE
}

BLACK AND WHITE PHOTOGRAPH

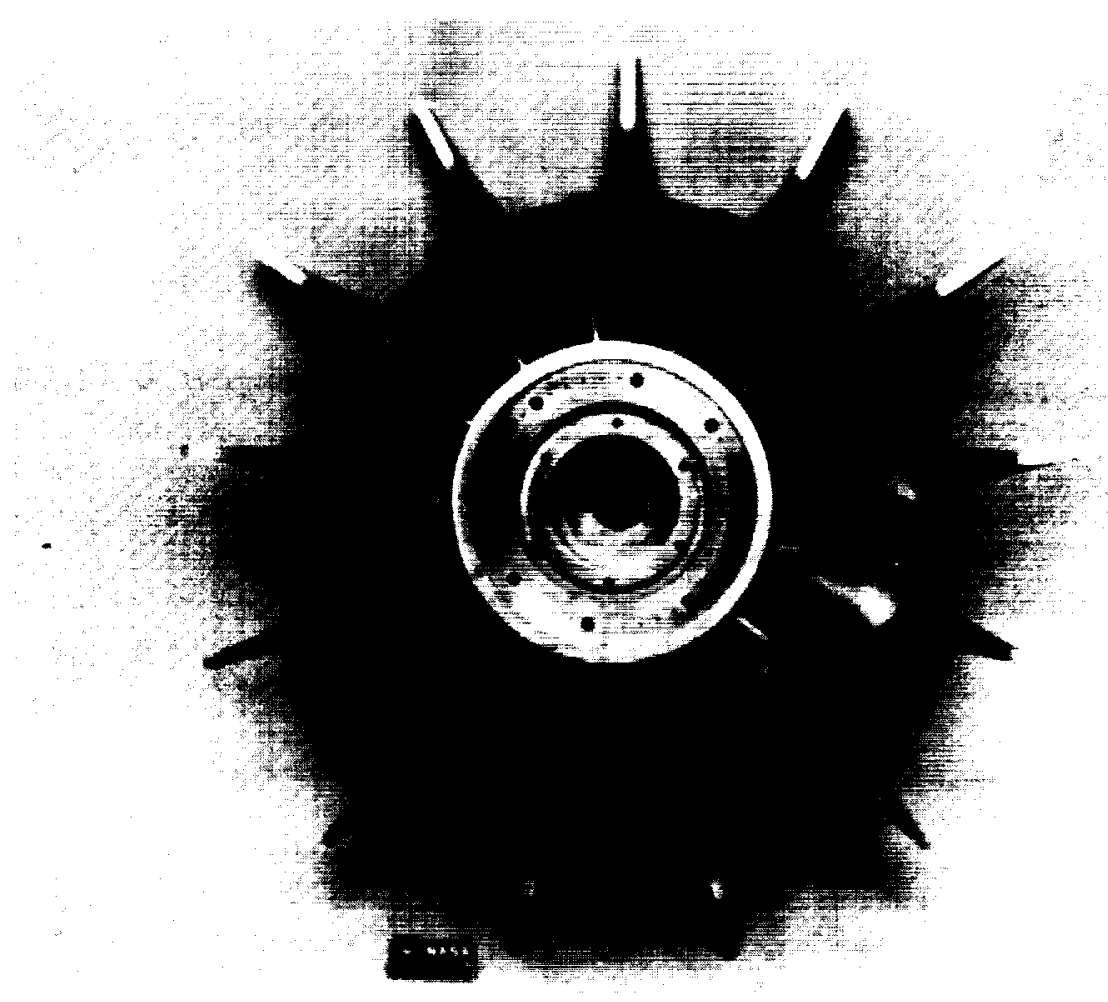

Figure 1. The solid rotor 


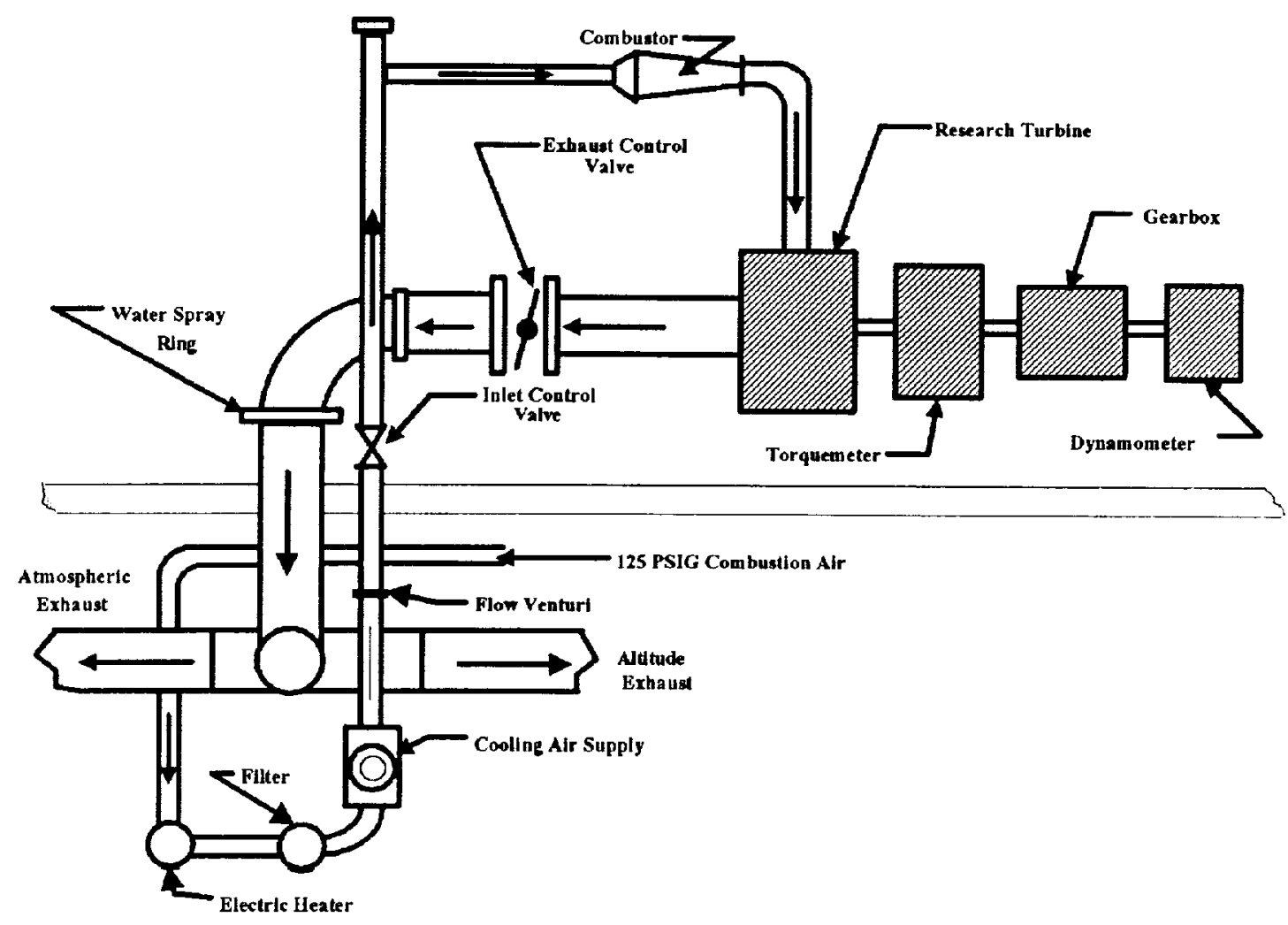

Figure 2. The Small Engine Component Test Facility (SECTF)

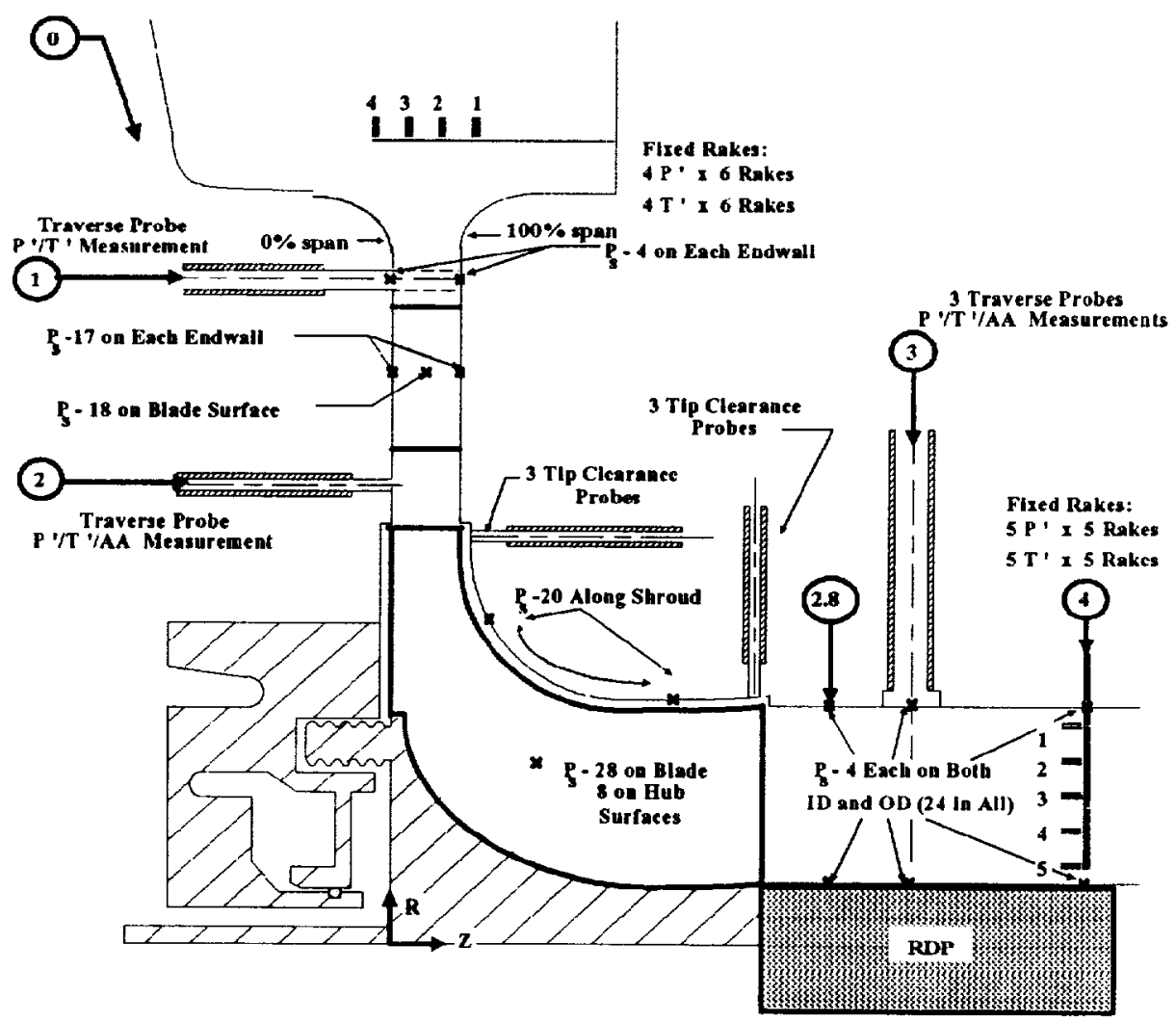

Figure 3. Research apparatus and instrumentation locations 


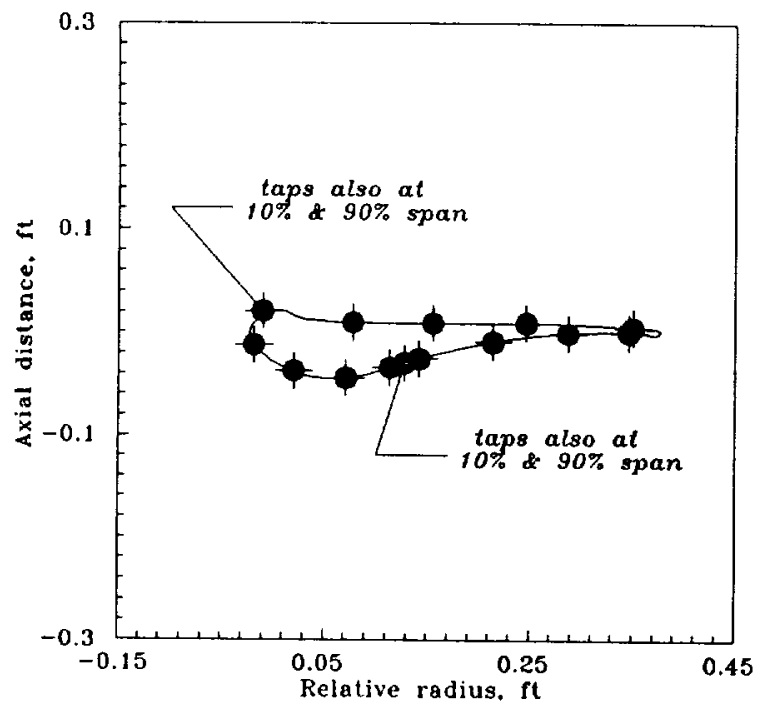

Figure 4. Vane static pressure tap locations.

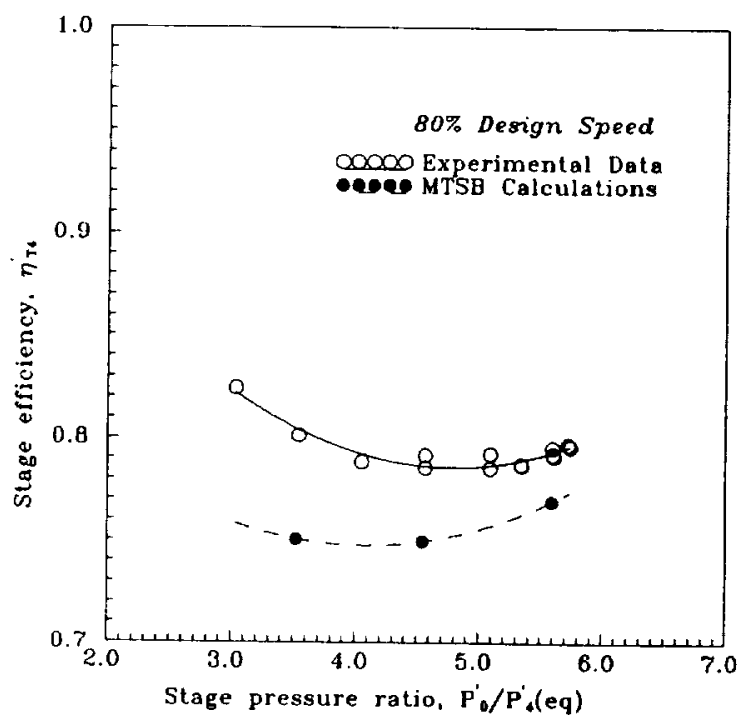

Figure 6. Total stage efficiency versus stage pressure ratio at $80 \%$ design speed.

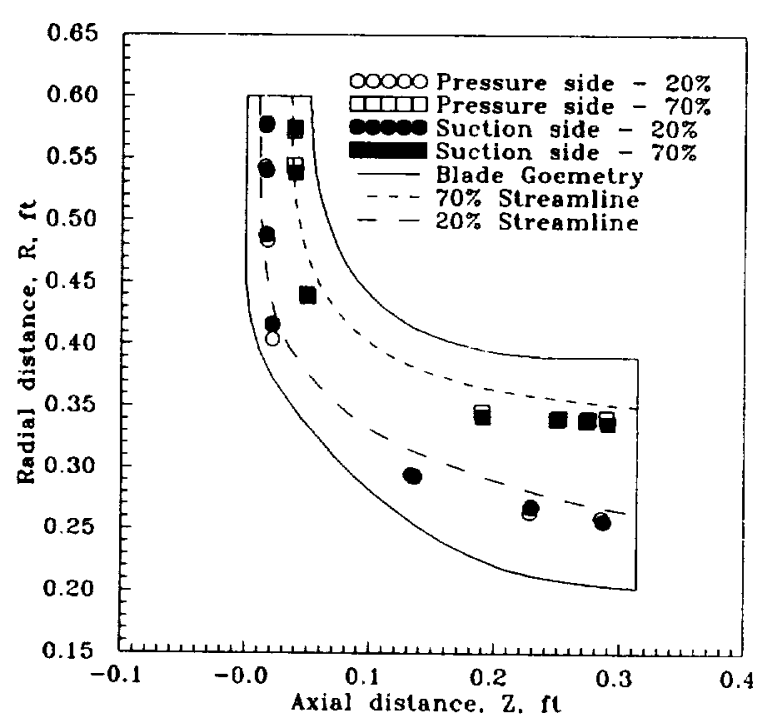

Figure 5. Rotor static pressure tap locations.

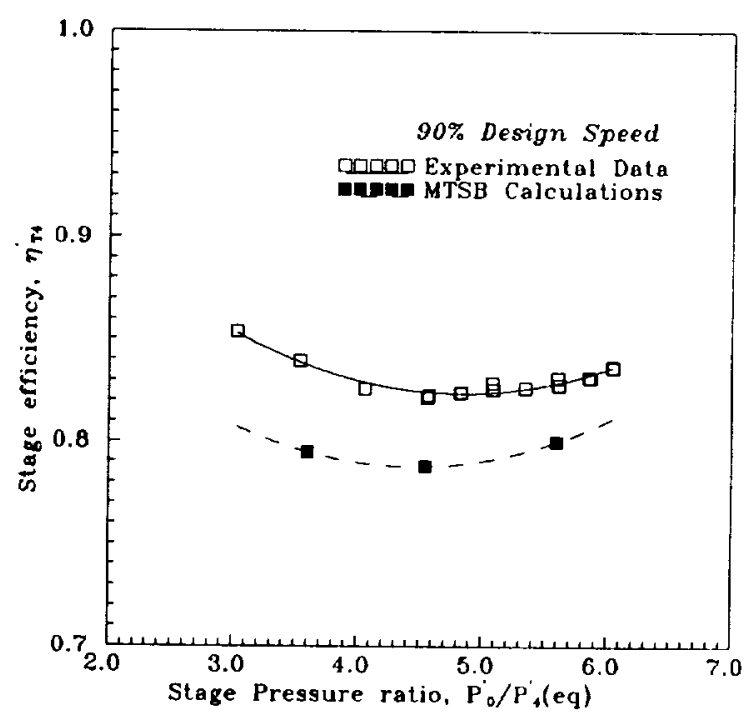

Figure 7. Total stage efficiency versus stage pressure ratio at $90 \%$ design speed. 


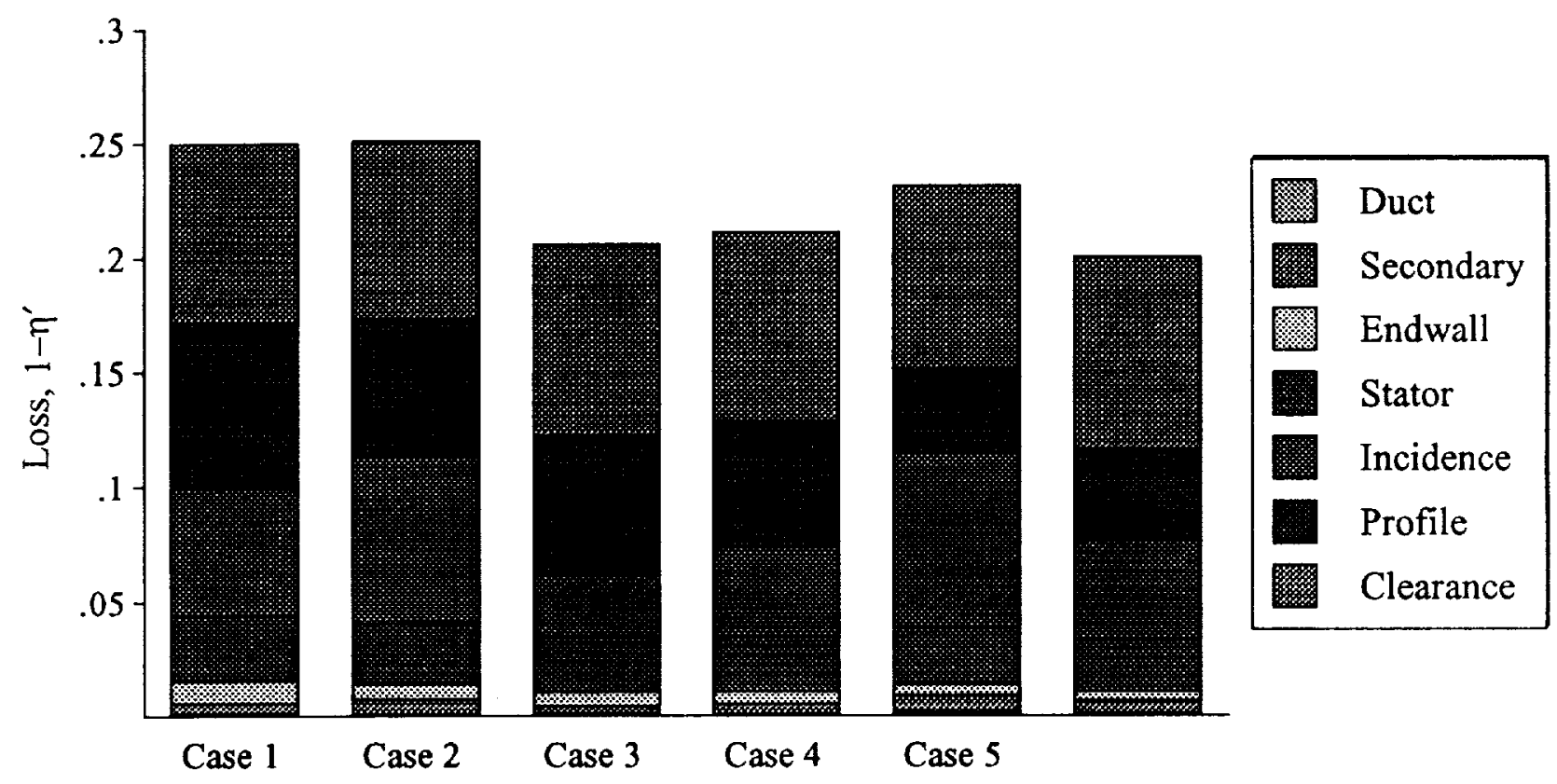

Figure 8. A breakdown of the calculated losses for each test case.

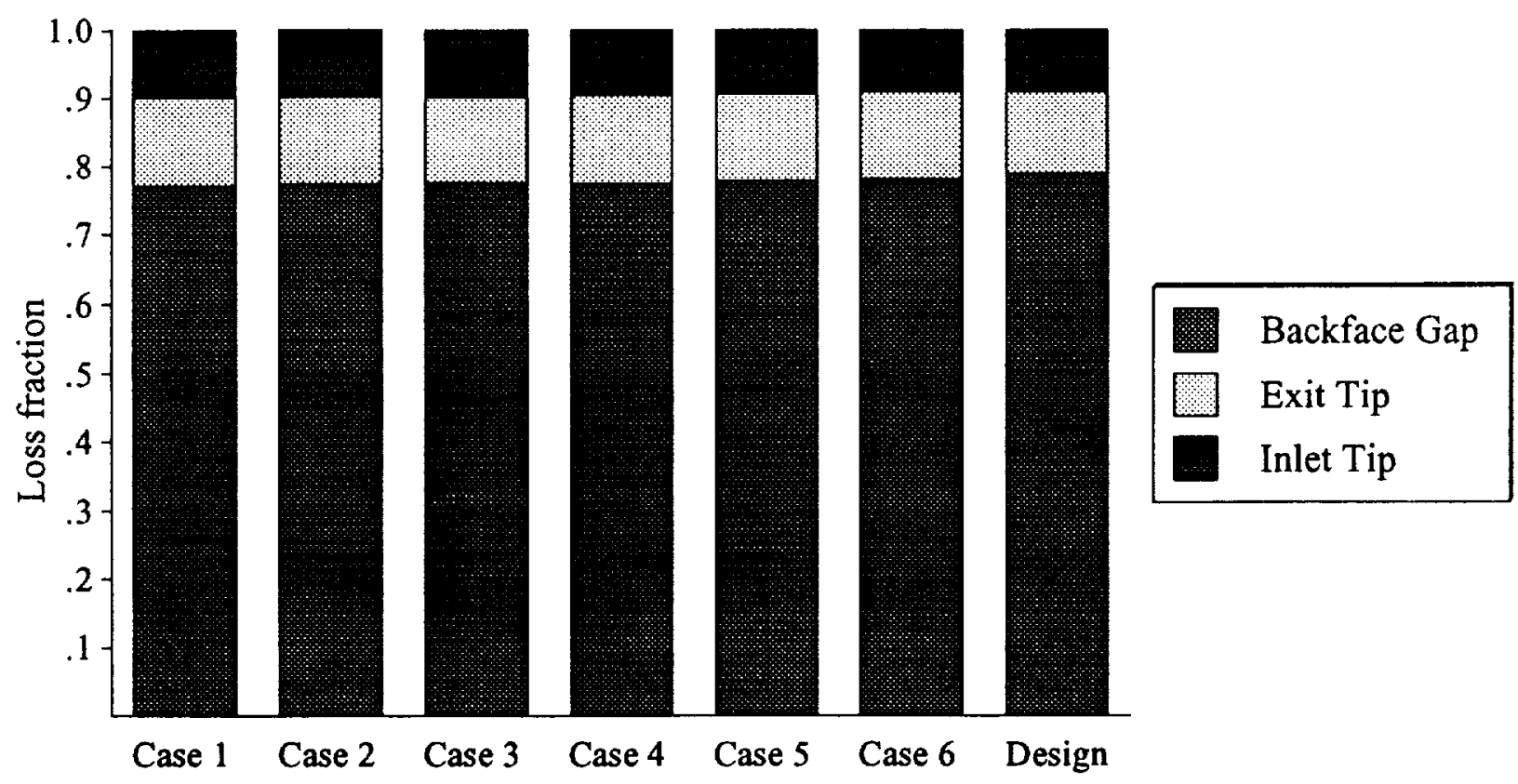

Figure 9. Fraction of clearance loss due to the three clearance components for each test case (including the design case). 

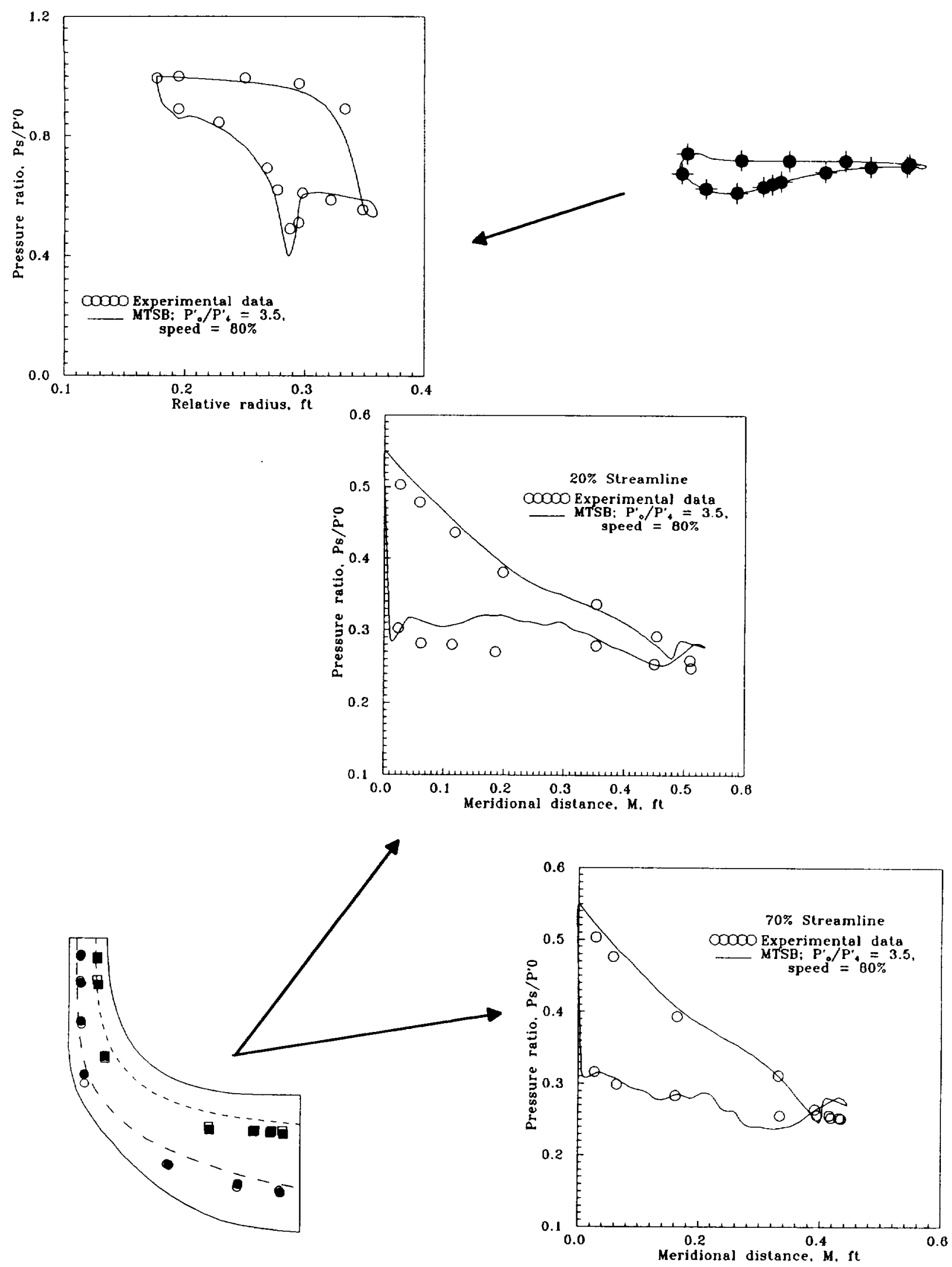

Figure 10. Case 1, static pressure comparison at $80 \%$ design speed and stage pressure ratio 3.5 . 

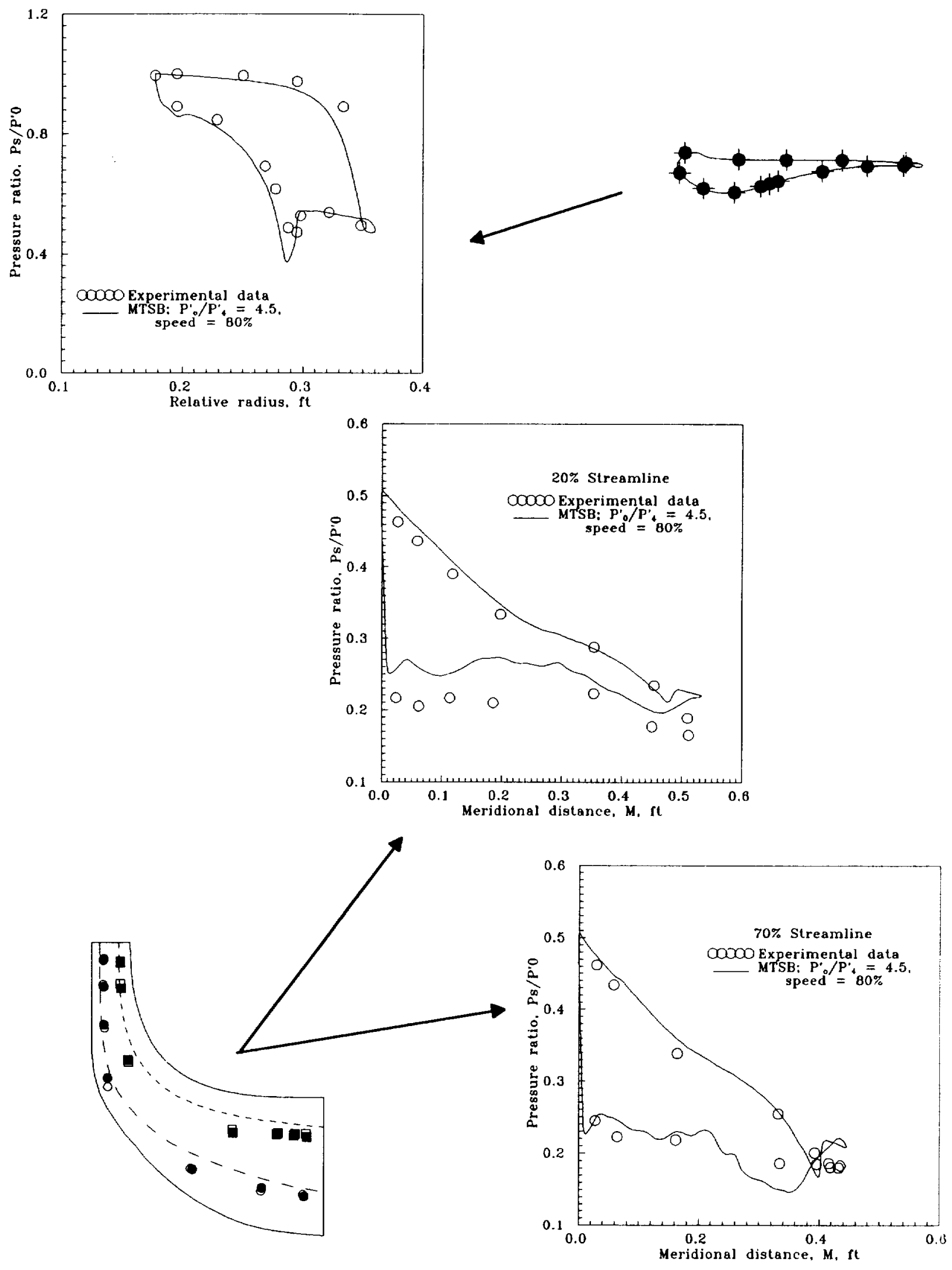

Figure 11. Case 2, static pressure comparison at $80 \%$ design speed and stage pressure ratio 4.5 . 

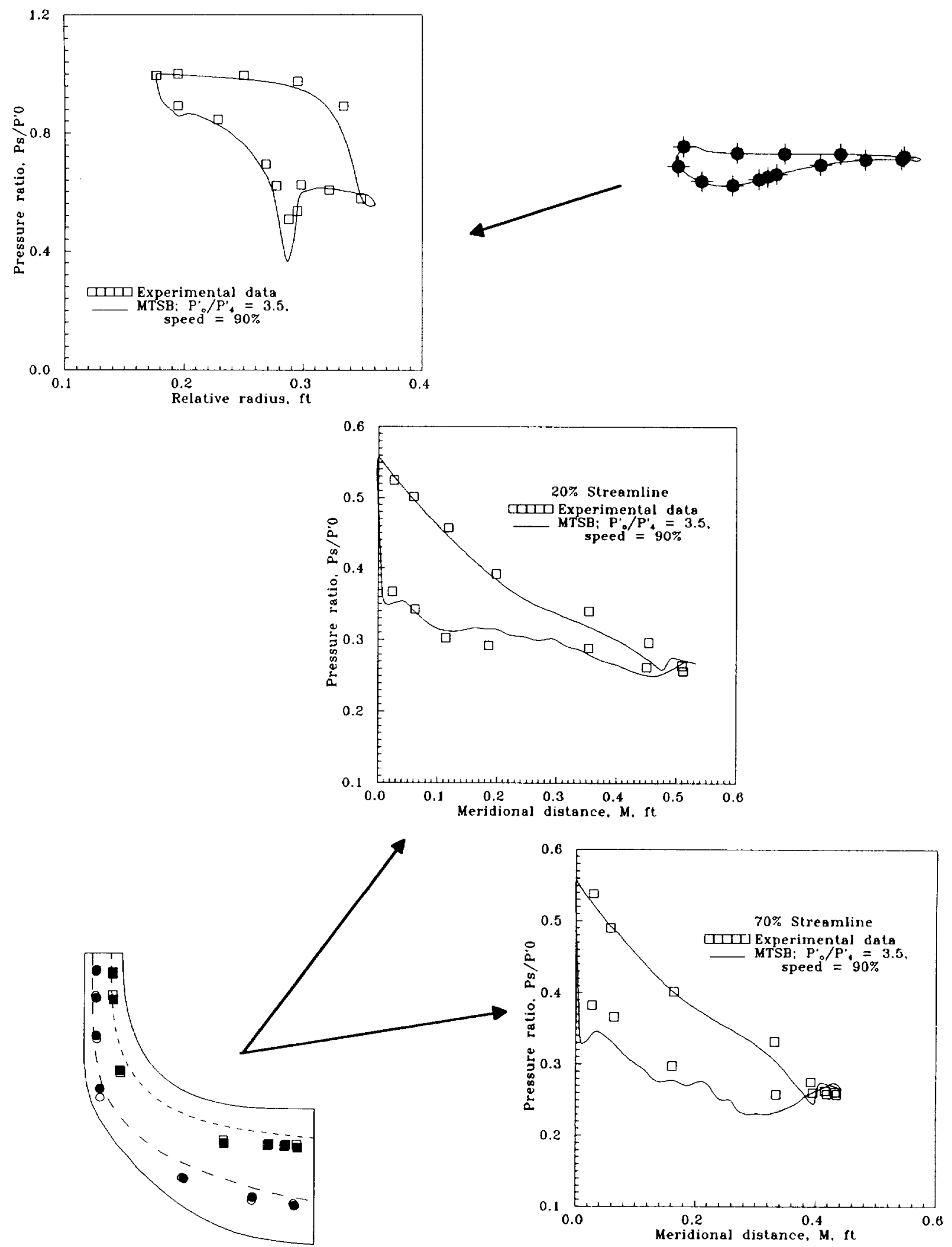

Figure 12. Case 3, static pressure comparison at $90 \%$ design speed and stage pressure ratio 3.5 . 

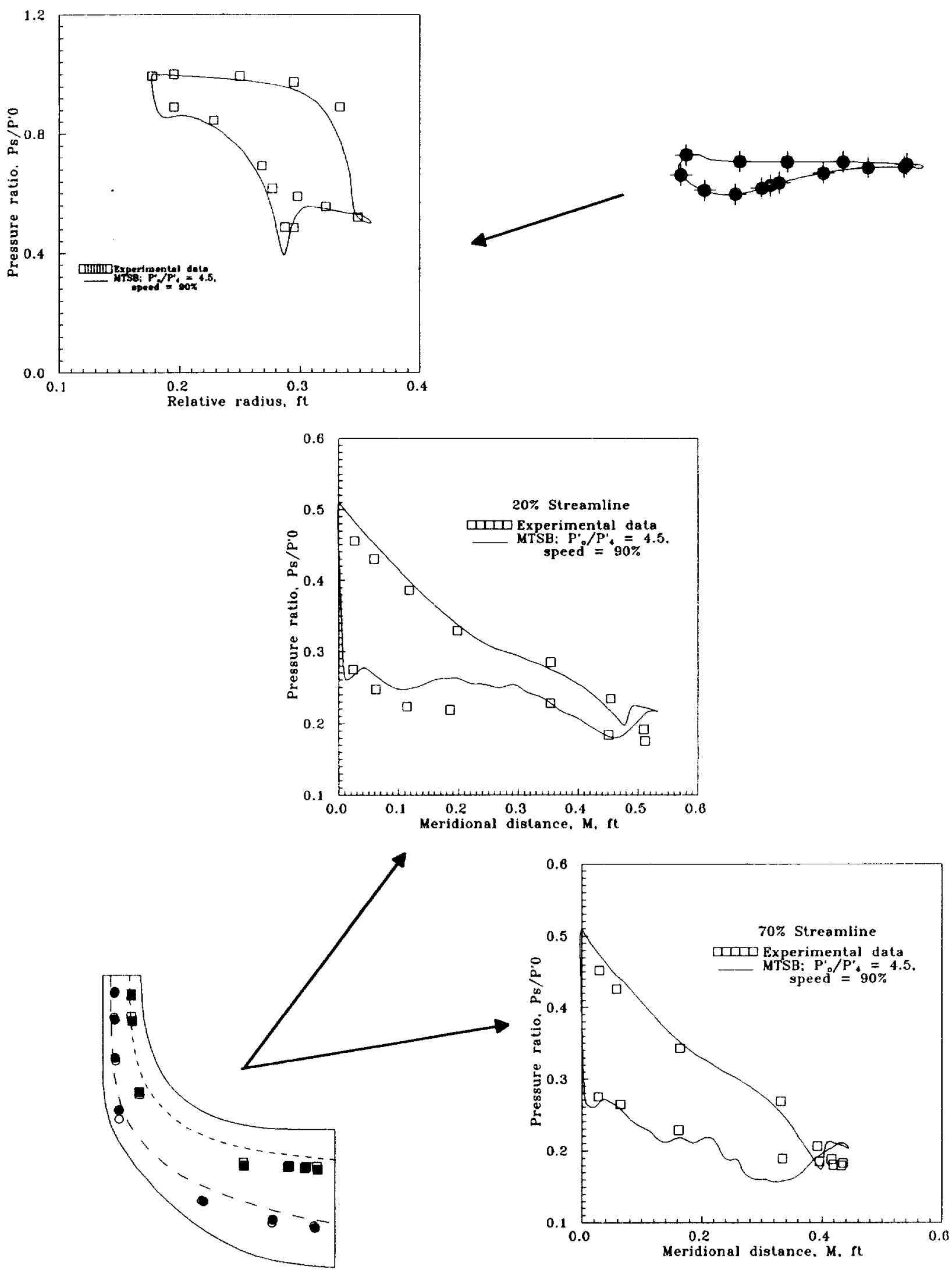

Figure 13. Case 4, static pressure comparison at $90 \%$ design speed and stage pressure ratio 4.5 . 
Public reporting burden for this collection of information is estimated to average 1 hour per response, including the time for reviewing instructions, searching existing data sources, gathering and maintaining the data needed, and completing and reviewing the collection of information. Send comments regarding this burden estimate or any other aspect of this coliection of intormation, including suggestions for reducing this burden, to Washington Headquarters Services, Directorate for information Operations and Reports. 1215 Jefterson Davis Highway. Suite 1204, Artington, VA 22202-4302, and to the Office of Management and Budget, Paperwork Reduction Project (0704-0188), Washington, OC. 20503.

\begin{tabular}{|l|c|c|}
\hline 1. AGENCY USE ONLY (Leave blank) & $\begin{array}{c}\text { 2. REPORT DATE } \\
\text { July } 1991\end{array}$ & $\begin{array}{r}\text { 3. REPORT TYPE AND OATES COVERED } \\
\text { Final Contractor Report }\end{array}$
\end{tabular}

\section{TITLE AND SUBTITLE}

A Comparison of the Calculated and Experimental Off-Design

Performance of a Radial Flow Turbine

6. AUTHOR(S)

Lizet Tirres

\section{PERFORMING ORGANIZATION NAME(S) AND ADDRESS(ES)}

Sverdrup Technology, Inc.

Lewis Research Center Group

2001 Aerospace Parkway

Brook Park, Ohio 44142

9. SPONSORING/MONITORING AGENCY NAMES(S) AND ADDRESS(ES)

National Aeronautics and Space Administration

Lewis Research Center

Cleveland, Ohio 44135-3191

\section{FUNDING NUMBERS}

WU-535-05--10
8. PERforming organization REPORT NUMBER

$E-7175$

11. SUPPLEMENTARY NOTES

Prepared for the 28th Joint Propulsion Conference and Exhibit cosponsored by the AIAA, SAE, ASME, and ASEE, Nashville, Tennessee, July 6-8, 1992. Lizet Tirres, Sverdrup Technology, Inc., Lewis Research Center Group, Cleveland, Ohio. Responsible person, Richard J. Roelke, (216) 433-3403.

12a. DISTRIBUTION/AVAILABILITY STATEMENT 12b. DISTRIBUTION CODE

Unclassified - Unlimited

Subject Category 02

13. ABSTRACT (Maximum 200 words)

Off-design aerodynamic performance of the solid version of a cooled radial inflow turbine is analyzed. Rotor surface static pressure data and other performance parameters were obtained experimentally. Overall stage performance and turbine blade surface static to inlet total pressure ratios were calculated by using a quasi-three-dimensional inviscid code. The off-design prediction capability of this code for radial inflow turbines shows accurate static pressure prediction. Solutions show a difference of 3 to 5 points between the experimentally obtained efficiencies and the calculated values.

14. SUBJECT TERMS

Turbines; Radial flow; Computational fluid dynamics

17. SECURITY CLASSIFICATION OF REPORT

Unclassified
18. SECURITY CLASSIFICATION OF THIS PAGE

Unclassified
19. SECURITY CLASSIFICATION OF ABSTRACT

Unclassifjed
15. NUMBER OF PAGES

16

16. PRICE CODE

A03

20. LIMITATION OF ABSTRACT 